UDC 621.396

doi: 10.26906/SUNZ.2018.1.064

O.V. Shefer

Poltava National Technical Yuri Kondratyuk University, Poltava

\title{
SYNTHESIS OF ADAPTIVE ALGORITHM OF COMPENSATION OF NONLINEAR DISTORTIONS OF RADIO DEVICES
}

As part of the article the scientifically grounded synthesis of the algorithm of adaptive compensation of nonlinear distortion (ACNLD) of radio devices based on the use of the mathematical apparatus of a theory of nonlinear analysis (Voltaire series). Actual speed and accuracy of adaptation were determined by choosing the optimal value of transmission coefficient. Some actual causes of limitation of dynamic range and appearance of internal noises of radio equipment were established. The estimation of ACNLD noise influence on its efficiency was carried out, and also the influence of signal component of the reference input ACNLD on radio quality indicators.

Keywords: radio device, adaptive compensator, non-linear distortion, internal noises, Voltaire series, dynamic characteristic.

\section{Introduction}

In order to increase the quality indicators of onboard radio local systems (OBRLS) of remote sensing of the Earth (RSE), on the basis of substantiation and application of adaptive methods of extending the linear dynamic range of their radio receiving devices (RRD), it is necessary to synthesize an adaptive method of inhibition of nonlinear distortions in radio devices (RD).

For this purpose, it is advisable to bring the conditions of this problem in line with the classical statement of the problem of adaptive compensation of interference in linear RRD $[1,2]$. Well-known linear adaptive compensators can be characterized by the presence of main and reference inputs that receive a mixture of useful signal with noise and interference respectively [1]. At the same time, the obstacle in the reference input is correlated only with the signal of interference from the main input and statistically non-interconnected (or less correlated) with a useful signal.

The purpose of the article: is the development of scientifically grounded device of adaptive compensation of nonlinear distortions of RD.

\section{The main part}

For the utilization of mathematic apparatus of the theory of adaptive systems [1, 3] with the aim of the formation of a task of adaptive compensation of nonlinear distortions, conditionally imagine an exit and input of one-dimensional RD according to the quality of the main and reference inputs of non-linear adaptive compensator. Mentioned inputs we will further call adaptive compensators of non-linear distortions (ACNLD) [1].

To study the physical opportunity of implementation and development of a scientifically grounded design of the ACNLD in relation to the problem of extending the linear dynamic range of RRD OBRLS, we will conduct an analysis of some qualitative characteristics of ACNLD constructed on the basis of real "noisy" elements with imperfect parameters.

Dynamic properties of adaptive compensators can be characterized by a long time adaptation (rearrangement) of adaptive filters $\tau$. In accordance with [4] it can be shown that usually rearrangement takes place under the exponential law. The time of adaptation of the ACNLD is determined by the following expression

$$
\tau_{\mathrm{ACNLD}}=\frac{\mathrm{k}_{\tau} \mathrm{m}}{4 \mu \mathrm{P}_{\mathrm{n}}},
$$

where $\mathrm{P}_{\mathrm{n}}-$ power compensation of nonlinear distortion; $\mathrm{k}_{\tau}$ - coefficient of proportionality.

Another major characteristic of the quality of adaptive compensators is the accuracy of adaptation, which is limited by gradient estimation errors $\omega_{1}$, as well as compensation errors due to the delay of the adaptation filter rebuild $\omega_{2}$. For ACNLDs, these errors can be determined, respectively, with formulas mentioned below [5]

$$
\begin{gathered}
\omega_{1}=\mathrm{k}_{\omega_{1}} \mu \mathrm{P}_{\mathrm{n}}, \\
\omega_{2}=\frac{1}{\mu} \frac{\mathrm{k}_{\omega 2} \sigma_{\mathrm{i}}^{2}}{4 \sigma_{\min }},
\end{gathered}
$$

where $\sigma_{\mathrm{H}}, \sigma_{\min }$ - respectively, medium quadratic error (MQE) of nonlinear distortions and the minimum MQE of adaptation, which is realized in the case of optimal construction of adaptive filters;

$\mathrm{k}_{\omega 1}, \mathrm{k}_{\omega 2}$ - coefficients of proportionality.

Consequently, the speed and precision of the ACNLD adaptation that are necessary for a particular task can be ensured by the appropriate choice of $\mu$ transmission coefficient of circle feedback (F) [6]. However, expressions (2) and (3) impose some contradictory requirements to the $\mu$ value. Therefore, the highest quality of adaptation (that is, a minimal total 
error $\omega_{\Sigma}=\omega_{1}+\omega_{2}=\min$ ) can be provided by choosing the optimal value of $\mu$, which can be found by the way of equating the right-hand sides of expressions (2) and (3) and can be determined by the formula [6]

$$
\mu_{\mathrm{opt}}=\sqrt{\frac{\mathrm{k}_{\omega 2} \sigma_{\mathrm{n}}^{2}}{4 \mathrm{k}_{\omega 1} \sigma_{\min } \mathrm{P}_{\mathrm{n}}}} .
$$

Actually, the achievable values of time of adaptation of $\tau$ of ACNLD are usually situated in the range from units and tens of ns to units of ms, which is usually sufficient for OBRLSs [6]. Therefore, in the process of developing the ACNLD, the main attention must be paid to the provision of specified requirements for the accuracy of ACNLD [6].

In well-known works devoted to the study of the influence of nonideal elements of adaptive compensators on the quality of their work, they were mainly taken into account only by errors in the implementation of the ratio of mathematical operations [7]. It is shown, in particular, that integration errors have a significant impact. Concerning ACNLD, the error of integration in the $\mathrm{k}$ channel leads to a compensation error, which is determined by the following formula $[6,7]$ :

$$
\lim _{\mathrm{t} \rightarrow \infty} \mathrm{W}_{\mathrm{k}}(\mathrm{t})=\mathrm{H}_{\mathrm{k}}+\Delta \mathrm{H}_{\mathrm{k}}
$$

where $\Delta \mathrm{H}_{\mathrm{k}}-$ the error is proportional to the error of integration.

Consequently, the requirements for the accuracy of the mathematical operations of the ACNLD elements must be set based on the maximum permissible, for this task, error of compensation of nonlinear distortions in the RRD OBRLS.

In the process of studying the effectiveness of adaptive compensators, as a rule, the effect of only external non-correlated influences is not the ideal optimal adaptive filter (Wiener filter) [8]. However, all real radio elements are "noisy", which causes the relevance of the analysis of the influence of internal noise ACNLD on its effectiveness [8], then we introduce the following notation [6]:

$$
v_{\mathrm{os}_{\text {inp }}}={ }^{\circ} \mathrm{P}_{\mathrm{N} 0} / \mathrm{P}_{\mathrm{n}} ; v_{\mathrm{op}} \text { inp }={ }^{\circ} \mathrm{P}_{\mathrm{A} 0} / \mathrm{P}_{\mathrm{n}},
$$

where $\mathrm{P}_{\mathrm{N} 0}$ - power of internal noises of the $\mathrm{RD}$ at its output (on the "main" input of the ACNLD);

$\mathrm{P}_{\mathrm{A} 0}$ - the power of the internal noise of the ACNLD itself, listed on its input (on the main input of the ACNLD).

As an indicator of the efficiency of the real ACNLD, that is "noisy", we will choose the value

$$
\Theta \doteq \mathrm{P}_{\mathrm{S}} / \mathrm{P}_{\mathrm{n}}^{\prime} / \mathrm{P}_{\mathrm{S}} / \mathrm{P}_{\mathrm{n}}
$$

where $\mathrm{P}_{\mathrm{s}}-$ power of signal component of the RD's output signal; $\mathrm{P}_{\mathrm{n}}, \mathrm{P}_{\mathrm{n}}^{\prime}$ - the power of nonlinear distortions on the "main" input and output of the ACNLD, which is compensated, respectively.

Since internal noises $\mathrm{P}_{\mathrm{S}}$ and $\mathrm{P}_{\mathrm{A} 0}$ are not correlated with the input and output signals of the ACNLD, then the expression for its efficiency coincides with the formula of the efficiency of linear adaptive compensators, subject to the influence on their inputs of external uncorrelated signals $[6,8]$, that is,

$$
\Theta=\frac{\left[v_{\mathrm{os}_{\text {inp }}}+1\right]\left[v_{\mathrm{op}_{\text {inp }}}+1\right]}{v_{\mathrm{os}_{\text {inp }}}+v_{\mathrm{os}} v_{\text {inp }} v_{\mathrm{op}_{\text {inp }}}+v_{\mathrm{osi}}} .
$$

Expression (5) allows evaluating the effect of internal noise of the ACNLD on its efficiency numerically. It is seen that the internal noise of the ACNLD does not lead to a decrease in the quality of the functioning of the RD [3]. In cases where the internal noise of the ACNLD exceeds to the level of non-linear suppressive distortions, the value $\Theta=1$ that is physically equivalent to the automatic shutdown of the ACNLD and, accordingly, the autonomous mode of the RD.

It should be noted that taking into account the unessentialnesses of parameters of elements of adaptive compensators, in the general case are not limited to an analysis of the influence of the errors of the execution of functional mathematical operations. Significant influence on the qualitative characteristics of adaptive compensators performs inevitable nonlinear properties of real elements [8]. This is of particular importance for ACNLD, which are directly intended to suppress nonlinear distortions in the RD. Given the insufficient degree of study of these issues in the well-known literature, it is necessary to analyze the influence of nonlinearities of the AC of real elements of the ACNLD on qualitative characteristics. To do this, we represent the output signals of real devices, having reduced to the k-th degree, the amplifier of the feedback circle and the multipliers of adaptive filters in the form of Voltaire's series [9].

$$
\begin{gathered}
\left(\mathrm{x}_{\mathrm{k}}\right)^{+}=\beta_{1} \mathrm{x}+\beta_{2} \mathrm{x}^{2}+\ldots+\beta_{\mathrm{k}} \mathrm{x}^{\mathrm{k}}+\ldots \\
(\mu \varepsilon)^{+}=\mu_{1} \varepsilon+\mu_{2} \varepsilon^{2}+\ldots \\
\left(\mathrm{Z}_{\mathrm{k}}\right)^{+}=\mathrm{a}_{10}\left(\mathrm{x}_{\mathrm{k}}\right)^{+}+\mathrm{a}_{10}(\mu \varepsilon)^{+}+\mathrm{a}_{20} \times \\
\times\left[\left(\mathrm{x}_{\mathrm{k}}\right)^{+}\right]^{2}+\mathrm{a}_{11}\left(\mathrm{x}_{\mathrm{k}}\right)^{+}(\mu \varepsilon)^{+}+\mathrm{a}_{02}\left[(\mu \varepsilon)^{+}\right]^{2}+\ldots \\
\left(\mathrm{Z}_{\mathrm{k}}\right)^{+}= \\
=\mathrm{b}_{10}\left[\frac{1}{\mathrm{~S}}\left(\mathrm{y}_{1}\right)^{+}\right]+\mathrm{b}_{01}\left(\mathrm{x}_{\mathrm{k}}\right)^{+}+\mathrm{b}_{20}\left[\frac{1}{\mathrm{~S}}\left(\mathrm{y}_{1}\right)^{+}\right]^{2}+ \\
+\mathrm{b}_{11}\left[\frac{1}{\mathrm{~S}}\left(\mathrm{y}_{1}\right)^{+}\right]\left(\mathrm{x}_{\mathrm{k}}\right)^{+}+\mathrm{b}_{02}\left[\left(\mathrm{x}_{\mathrm{k}}\right)^{+}\right]^{2}+\ldots
\end{gathered}
$$


where $\left(\mathrm{x}_{\mathrm{k}}\right)^{+},(\mu \varepsilon)^{+},\left(\mathrm{y}_{1}\right)^{+},\left(\mathrm{y}_{2}\right)^{+},\left(\mathrm{z}_{\mathrm{k}}\right)^{+}-$output signals of real $\mathrm{k}$-th power reduction devices, feedback amplifier, k-th adaptive first multiplier, second $\mathrm{k}$-th adaptive filter multiplier ( $\mathrm{k}$ adaptive filter), respectively; $\beta_{i}, \mu_{j}, a_{i j}, b_{i j}-$ NLTF of specified elements of the ACNLD, respectively.

Nonlinearities of the AC of the amplifier of the circle of feedback lead to a limitation of the upper limit of the dynamic range at the exit of the ACNLD $\varepsilon_{\max }$ [9]. The permissible level of nonlinear distortion in the amplifier of the circle of feedback can be determined from the given upper level of the dynamic range at the output of the ACNLD, for the narrow band amplifier we have, for the broadband amplifier

$$
\left|\mu_{3}\right| \leq \frac{1}{\left|\varepsilon_{\max z}\right|^{2}} ;
$$

for a broadband amplifier

$$
\left.\begin{array}{c}
\left|\mu_{2}\right| \leq \frac{1}{\mathrm{k}_{\mu}\left|\varepsilon_{\max z}\right|} \\
\left|\mu_{3}\right| \leq \frac{1}{\left(1-\mathrm{k}_{\mu}\right)\left|\varepsilon_{\max z}\right|^{2}}
\end{array}\right\},
$$

where $k_{\mu}-$ the coefficient, which determines the correlation between the admissible levels of nonlinear distortions of the second and third orders $\left(0 \leq k_{\mu} \leq 1\right)$ and depends on the width of the bandwidth of the amplifier of the circle of feedback. The nonlinear properties of the device in the k-th degree lead to a distortion of the output k-th adaptive filter [6]. It follows from (10) that

$$
\begin{aligned}
& \left(\mathrm{W}_{\mathrm{k}}(\mathrm{t})\right)^{+}=\mathrm{W}_{\mathrm{k}}(\mathrm{t})+\Delta \mathrm{W}_{\mathrm{k}}(\mathrm{t}) \cong \\
& \cong \mathrm{W}_{\mathrm{k}}(\mathrm{t})+\sum_{\mathrm{i}=1, \mathrm{i} \neq \mathrm{k}}^{\infty}\left[\beta_{\mathrm{i}} \mathrm{W}_{\mathrm{k}}(\mathrm{t})\right],
\end{aligned}
$$

where $\left[\beta_{\mathrm{i}} \mathrm{W}_{\mathrm{k}}(\cdot)\right]-\mathrm{H} \Phi \mathrm{t}-\mathrm{th}$ degree.

It's necessary to mention that a member $\beta_{\mathrm{k}}+2 \mathrm{~W}_{\mathrm{k}}(\cdot)$ defines the limits of the dynamic range of the ACNLD at its entrance; constituent $\beta_{\mathrm{i}} \mathrm{W}_{\mathrm{k}}(\cdot)$ causes distortion of the output signal of the $\mathrm{j}$-th (adjacent) channel of the ACNLD; the component $\beta_{\mathrm{n}} \mathrm{W}_{\mathrm{k}}(\cdot)$ leads to distortion of the useful component of the output signal of the RD, components $\beta_{\mathrm{i}} \mathrm{W}_{\mathrm{k}}(\cdot)$ $(\mathrm{i} \neq \mathrm{k}, \mathrm{k}+2, \mathrm{n}, \mathrm{j})$ increase the internal noise of the ACNLD [5].

Additional noise level can be found as [8]

$$
\Delta \mathrm{N}_{\mathrm{A}} \cong\left|\sum_{\mathrm{i}} \sum_{\mathrm{i}=1, \mathrm{i} \neq \mathrm{k}}^{\mathrm{m}} \beta_{\mathrm{l}_{\mathrm{i}}} \mathrm{W}_{\mathrm{l}}(\mathrm{t}) \mathrm{X}_{\mathrm{i}}\right| \text {, }
$$

where $1-$ is a number of a channel ACNLD; $\beta_{l_{i}}-$ НПФ 1-th degree in the mechanism of reduction in the 1-th degree of the 1 channel ACNLD.

An error introduced in the $\mathrm{k}$-th channel of the ACNLD at the expense of its other channels is defined as following [10]

$$
\Delta \mathrm{W}_{\mathrm{k}}^{\prime}(\mathrm{t}) \cong\left|\sum_{\substack{\mathrm{l}=1 \\ l \neq \mathrm{k}, \mathrm{n}}}^{\mathrm{m}} \beta_{\mathrm{l}_{\mathrm{k}}} \mathrm{W}_{1}(\mathrm{t})\right| .
$$

It also follows from the expression that the upper limit of its range at the input of the ACNLD Xmax (according to non-linear distortions of the k-order), taking into account the influence of all its channels, depends on the $\Delta \mathrm{W}^{\prime \prime} \mathrm{k}(\mathrm{t})$, which is determined from the ratio of this form

$$
\Delta \mathrm{W}_{\mathrm{k}}^{\prime \prime}(\mathrm{t}) \cong\left|\sum_{\substack{\mathrm{l}=1 \\ 1 \neq \mathrm{n}}}^{\mathrm{m}} \beta_{\mathrm{l}_{\mathrm{k}+2}} \mathrm{~W}_{\mathrm{l}}(\mathrm{t})\right|
$$

You can determine the requirements for the nonlinearity $(\mathrm{k}+2)$-th order of the reduction devices in the degree

$$
\left|\sum_{1=1,1 \neq n}^{m} \beta_{l_{k+2}}\right| \leq\left|\frac{H_{k}(t)}{H_{n}(t)}\right|^{2} \frac{1}{\left|X_{\max }\right|^{|k-n|}},
$$

To evaluate the distortion of the signal component of the output signal of the RD, we define the signal / noise ratio at the $\operatorname{ACNLD} \rho_{o_{\text {inp }}}$ reference input as follows

$$
\begin{gathered}
\rho_{\mathrm{o}_{\text {inp }}}= \\
=\left|\sum_{\mathrm{l}=1, \mathrm{l} \neq \mathrm{n}}^{\mathrm{m}} \beta_{\mathrm{l}_{\mathrm{n}}} \mathrm{W}_{\mathrm{l}}(\mathrm{t}) \mathrm{X}_{1} / \sum_{\mathrm{l}=1, \mathrm{l} \neq \mathrm{n}}^{\mathrm{m}} \beta_{\mathrm{l}_{1}} \mathrm{~W}_{\mathrm{l}}(\mathrm{t}) \mathrm{X}_{\mathrm{l}}\right|,
\end{gathered}
$$

Then the signal / noise ratio at the output is equal

$$
\rho_{\text {out }}=\frac{1}{\rho_{\mathrm{o}_{\text {inp }}}} \text {. }
$$

Accordingly, the distortion of the signal component of the output signal of the $\mathrm{RD}$ at the output of the ACNLD can be defined as

$$
\varepsilon=\frac{\rho_{\mathrm{o}_{\text {inp }}}}{\rho_{\mathrm{os}_{\text {inp }}}},
$$

where $\rho_{\mathrm{os}_{\text {inp }}}$ - signal / noise ratio at the output of the $\mathrm{RD}$, which is determined in this case by the formula

$$
\rho_{\mathrm{os}_{\text {inp }}}=\left|\mathrm{H}_{\mathrm{n}} \mathrm{X}_{\mathrm{n}} / \sum_{\mathrm{k}=1, \mathrm{k} \neq \mathrm{n}}^{\mathrm{m}}\left(\mathrm{H}_{\mathrm{k}} \mathrm{X}_{\mathrm{k}}\right)\right| \text {. }
$$


The signal component in the reference input of the ACNLD also causes a change in the nonlinear distortion spectrum that is compensated

$$
\left\{\mathrm{S}_{\mathrm{Y}}\right\}_{\text {outp }}=\left\{\mathrm{S}_{\mathrm{Y}}\right\}_{\mathrm{os}_{\text {inp }}} \rho_{\mathrm{o}_{\text {inp }}} \rho_{\mathrm{o}_{\text {inp }}},
$$

where $\left\{\mathrm{S}_{\mathrm{Y}}\right\}_{\text {outp }},\left\{\mathrm{S}_{\mathrm{Y}}\right\}_{\text {os }}$ - the spectrum of nonlinear distortions, which are compensated for the output of the ACNLD and the output of the RD, respectively. Formulas (17) and (19) allow numerically estimate the effect of the signal component in the ACNLD reference input on its qualitative characteristics. The requirements for the level of non-linear distortions of the $n$-th order can be determined from the maximum allowable value $\rho_{\mathrm{o}_{\text {inp }} \mathrm{d}}$, then

$$
\left|\beta_{\Pi}\right| \leq \rho_{o_{\text {inp }} d} \cdot
$$

It can be shown that the requirements for the level of nonlinear distortion of the multiplier of adaptive filters are substantially lower than the corresponding requirements for the nonlinearities of the $\mathrm{AC}$ of the reduction devices in degree [11]. Given the fact that it is most convenient to implement step-by-step devices on the basis of a multiplier [12], there are all grounds for ensuring that the requirements for the level of nonlinear distortions of all multipliers are the same and meet the requirements that are presented to the reduction devices in the degree.

The results obtained above can be used not only for the ACNLD, but also for the analysis of qualitative characteristics of a wide class of adaptive and selfadjusting systems, taking into account internal noise and nonlinear properties of their elements [11].

Regarding the tasks, we will use the results of the study of the characteristics of the accuracy and dynamic characteristics of the real ACNLD for the development of scientifically based methodology for their design in order to expand the linear dynamic range RRD OBRLS.

Let the linear dynamic range of RP be equal

$$
\begin{gathered}
D_{1}=D_{\text {linp }}= \\
=20 \lg \left|\frac{X_{\text {max }}^{\prime}}{X_{\text {min }}^{\prime}}\right| \cong D_{\text {loutp }}=20 \lg \left|\frac{Y_{\text {max }}^{\prime}}{Y_{\text {min }}^{\prime}}\right|,
\end{gathered}
$$

where $\left|\mathrm{X}_{\text {min }}^{\prime}\right|,\left|\mathrm{Y}_{\text {min }}^{\prime}\right|\left(\left|\mathrm{X}_{\max }^{\prime}\right|,\left|\mathrm{Y}_{\max }^{\prime}\right|\right)$ - lower (upper) limit of the dynamic range of the $\mathrm{RD}$ to the input and output, respectively.

Assume that you need to expand the dynamic range of the $R D$ to a value $D>D_{1}$, where

$$
\begin{gathered}
\mathrm{D}=\mathrm{D}_{\text {inp }}=20 \lg \left|\frac{\mathrm{X}_{\text {max }}}{\mathrm{X}_{\text {min }}^{\prime}}\right| \cong \\
\cong \mathrm{D}_{\text {outp }}=20 \lg \left|\frac{\mathrm{Y}_{\text {max }}}{\mathrm{Y}_{\text {min }}^{\prime}}\right|,
\end{gathered}
$$

$$
\left|\frac{X_{\text {max }}}{X_{\text {min }}^{\prime}}\right| \cong\left|\frac{Y_{\text {max }}}{Y_{\text {min }}^{\prime}}\right|>1 \text {. }
$$

Designing the ACNLD is advisable to start with the choice of an adder, the dynamic range $\mathrm{D}_{\Sigma}$ of which should be at least $\mathrm{D}$, that is $\mathrm{D}_{\Sigma} \geq \mathrm{D}$, and, moreover

$$
\left|\varepsilon_{\sum \min }\right| \leq\left|Y_{\min }^{\prime}\right| ;\left|\varepsilon_{\sum \max }\right| \geq\left|Y_{\max }\right|
$$

where $\left|\varepsilon_{\sum \min }\right|\left(\left|\varepsilon_{\Sigma} \max \right|\right)$ - lower (upper) limit of the adder band (subtraction device).

Determine the requirements for the accurate integrity of $\Delta$ int. Since non-linear distortions of the k-th order are practically and appropriately suppressed only with the accuracy to nonlinear distortions of higher (first-order $(\mathrm{k}+2)$-th) orders, then for the cascades of the RRD of the OBRLS [5, 6]:

$$
\Delta_{\text {int }} 1 \leq \Delta \mathrm{H}_{3} \mathrm{z} \leq\left|\mathrm{H}_{5}\right|,
$$

and for coherent detectors and frequency converters [14]

$$
\Delta_{\text {int }} 2 \leq \Delta \mathrm{H}_{31} \mathrm{z} \leq\left|\mathrm{H}_{51}\right| .
$$

Let's find the requirements for the parameters of the assembly devices in the degree and multiplier of the ACNLD. Given the one-channel ACNLD, from the expressions (21) and (26), one can determine the permissible nonlinearity factor of the multiplier in case of amplifying cascades of the RRD of the OBRLS [13]

$$
\left|\beta_{1}\right|=\left|a_{i j}\right|=\left|b_{i j}\right| \leq\left|\frac{\mathrm{H}_{3}}{H_{1}}\right|^{2} \frac{1}{\left|X_{\max }\right|^{2}} ;,
$$

$\rho_{\mathrm{o}_{\text {inp }} \mathrm{d}}$ as well as for coherent detectors and frequency converters $[5,7]$

$$
\left|\beta_{1}\right|=\left|a_{i j}\right|=\left|b_{i j}\right| \leq\left|\frac{H_{31}}{H_{11}}\right|^{2} \frac{1}{\left|X_{\max }\right|^{2}} ; \quad \rho_{o_{\text {inp }} d},
$$

where $1=\mathrm{i}+\mathrm{j} \neq 2$; (ij) $\neq(11) ; \mathrm{X}_{\mathrm{o}}$ - amplitude of the reference signal (the signal of the heterodyne).

The requirements for the admissible nonlinearity of the AC amplifier of feedback range can be given from the required value

$$
\left|\mathrm{Y}_{\max }\right| \leq\left|\varepsilon_{\text {max зад }}\right| \doteq\left|\varepsilon_{\sum \max }\right| .
$$

In this case, the transfer coefficient of the amplifier of the feedback circle must be found from the required accuracy and speed of adaptation for the given task [4].

In some cases, the optimal value $u_{\text {opt }} \equiv \mu_{1 \text { opt }}$ lies in the range from 0.1 to 10 , and for cascades $\mu_{\text {lopt }} \leq 1$, and for final and transformation cascades $\mu_{\text {lopt }} \geq 1[6,9]$. 
Consequently, we get an expression for Voltaire's kernels in operator form

$$
\mathrm{H}_{1}(\mathrm{p})=\frac{1}{\mathrm{p}+\mathrm{U}_{\mathrm{C}} \mathrm{K}(\mathrm{p})} \text {. }
$$

As can be seen from formula (24), internal noise must not exceed the level of compensated nonlinear distortion [7]. In order not to render unreasonably overestimated requirements to the fluctuation characteristics of the elements of the ACNLD, it is necessary to ensure that the conditions $[4,6]$

$$
\left|\mathrm{X}_{\min }^{\prime \prime}\right| \leq\left|\mathrm{X}_{\max }^{\prime}\right| \text {, }
$$

where $\left|X_{\min }^{\prime \prime}\right|$ - the lower limit of dynamic range of the ACNLD. The required dynamic range of the ACNLD $\mathrm{D}_{2}$ can be determined from the inequality $[4,6]$ $D_{2} \geq D-D_{1}$. As a result, there is an important practical conclusion that, for the construction of the ACNLD, with the task of extending the linear dynamic range of the RRD OBRLS, there is no need for silent elements with ideal parameters and those that cannot be physically realized.

\section{Conclusions}

It is established, that a synthesized adaptive method of compensation of non-linear disfigurations can be physically realized on the basis of distinguished radio elements. Final and authentic conclusion about the practical realization and the ability of AKHC to work, and also their real qualitative characteristics and opportunities can be made on the basis of experimental confirmation of the main results of the theoretic analysis of accuracy and dynamic characteristics of non-linear adaptive compensators.

\section{References}

1. Radioelektronnyie sistemyi: osnovyi postroeniya $i$ teoriya. / Ed. by Ya. D. Shirmana. - Moscow: ZAO MAKVIS, 1998. - P. 828.

2. Polyak B. T. Robastnyie algoritmyi adaptatsii / B. T. Polyak, Ya. Z. Tsyipkin // Avtomatika i telemehanika. - 1980. - no 10. pp. 91-97.

3. Gutkin L.S. Proektirovanie radiosistem $i$ radioustroystv. - M.: Radio i svyaz, 1986. - P. 288.

4. Kapalin V. I. Neyrosetevoe modelirovanie sistem upravleniya / V. I. Kapalin, I. V. Vitohin, Nguen Dun Chin. // Nauchnyie vedomosti BelGU. - 2009. - \#9(64), vyip.11/1. pp. 87-92.

5. Kim D. P. Teoriya avtomaticheskogo upravleniya / D. P. Kim // Tom 2. Mnogomernyie, nelineynyie, optimalnyie sistemyi. - M.: FIZMATLIT, 2004. - P. 464.

6. Maas, Stephen A. Nonlinear microwave and RF circuits / Stephen A. Maas. - 2nd ed. Boston; London: Artech House. - 2003. $-582 p$.

7. Nevdyaev L. M. Personalnaya sputnikovaya svyaz / L. M. Nevdyaev, A. A. Smirnov. - M.: Eko-Trendz, 1998. - P. 215.

8. Radiotehnicheskie sistemyi / Pod red. Yu. M. Kazarinova. - M.: V. shkola, 1990. - P. 496.

9. Graham $S$. W. Nonlinear System Modeling and analysis with Applications to Communicatios Receivers / S. W. Graham, L. Ehrman // RADC-TR-73-178, ASIA, AD766278. Rome-New York, 1973.

10. Shetsen M. Modelirovanie nelineynyih sistem na osnove teorii Vinera / M. Shetsen // TIIER. - 1981. - T.69, no 12, - pp. 44-62

11. Lityuk V.I. Printsipyi tsifrovoy mnogoprotsessornoy obrabotki ansambley radiosignalov / V.I. Lityuk. - M.: SOLON-PRESS, 2007. -592 p.

12. Bogdanovich B. M. Radiopriemnyie ustroystva / B. M. Bogdanovich, N. I. Okulin. - Minsk: V. shkola, 1991. $428 \mathrm{p}$.

Надійшла до редколегії 10.01.2018

Рецензент: д-р техн. наук, професор С. В. Козелков, Державний університет телекомунікацій, Київ.

\title{
СИНТЕЗ АДАПТИВНОГО АЛГОРИТМУ КОМПЕНСАЦІІ НЕЛІНІЙНІХ СПОТВОРЕНЬ РАДІОПРИСТРОЇВ
}

\author{
O.В. Шефер
}

У рамках статті проведений науково обтрунтований синтез алгоритму адаптивної компенсаиії нелінійних спотворень (АКНС) радіопристроїв на основі використання математичного апарату теорії нелінійного аналізу (рядів Вольтера). Визначена реальна швидкість і точність адаптачії шляхом вибору оптимального значення коефіцієнта передачі. Встановлені фактичні причини обмеження динамічного діапазона та появи внутрішніх шумів радіопристроїв. Проведена оиінка впливу шумів АКНС на ефективність ї̈ роботи, а також вплив сигнальної складової в опорному вході АКНС на показники якості радіопристроїв.

Ключові слова: радіопристрій, адаптивна компенсаиія, нелінійне спотворення, внутрішні шуми, ряди Вольтера, динамічні характеристики.

\section{СИНТЕЗ АДАПТИВНОГО АЛГОРИТМА КОМПЕНСАЦИИ НЕЛИНЕЙНЫХ ИСКАЖЕНИЙ РАДИОУСТРОЙСТВ}

\section{А.В. Шефер}

В рамках статьи проведен научно обоснованный синтез алгоритма адаптивной компенсации нелинейных искажений (АКНИ) радиоустройств на основе использования математического аппарата теории нелинейного анализа (рядов Вольтерра). Определена реальная скорость и точность адаптации путем выбора оптимального значения коэффициента передачи. Установлены фактические причины ограничения динамического диапазона и появления внутренних шумов радиооборудования. Проведена оценка влияния шумов АКНИ на эффективность ее работы, а также влияние сигнальной составляющей в опорном входе АКНИ на показатели качества радиооборудования.

Ключевые слова: радиоустройство, адаптивная компенсация, нелинейное искажение, внутренние иумы, ряды Вольтерра, динамические характеристики. 